\title{
Activation of the Human Contact System on Neutrophil Extracellular Traps
}

\author{
Sonja Oehmcke Matthias Mörgelin Heiko Herwald \\ Department of Clinical Sciences, Division of Infection Medicine, Lund University, Lund, Sweden
}

\begin{abstract}
Key Words
Contact system • DNA-protein interaction • Immunity • Innate $\cdot$ Polymorphonuclear leukocytes $\cdot$ Streptococcus
\end{abstract}

\begin{abstract}
Pattern recognition is an integral part of the innate immune system. The human contact system has been shown to interact with the surface of many bacterial and fungal pathogens, and once activated leads to the generation of antimicrobial peptides and the proinflammatory mediator bradykinin. Here we show that apart from these surfaces also neutrophil extracellular traps (NETs) provide a surface that allows the binding and activation of the contact system. In addition, we present evidence that M1 protein, a streptococcal surface protein, in concert with human fibrinogen triggers polymorphonuclear neutrophils to form NETs.
\end{abstract}

Copyright $\odot 2009$ S. Karger AG, Basel

\section{Introduction}

Apart from antimicrobial peptides, leukocyte-borne proteinase, and reactive oxidative species, polymorphonuclear neutrophils (PMNs) may also release their nuclear content to form web-like structures upon activation. These neutrophil extracellular traps (NETs) consist of DNA and granule-derived proteins such as neutrophil elastase, cathepsin G, bactericidal/permea- bility-increasing protein and antimicrobial peptides [1, 2]. As such, NETs are capable to assemble and kill various bacterial and fungal species and, thus, they are now considered as an important part of the innate immune system [1]. Assuming that most neutrophil-released proteins stick to NETs because of their positive net charge, it is tempting to speculate that also other positively charged proteins, derived for instance from plasma, interact with NETs. Notably, activation of the contact system requires the assembly of its factors on a negatively charged artificial or biological surface [3-6]. The contact system comprises 3 serine proteinases factor XI (FXI), factor XII (FXII), plasma kallikrein (PK) and 1 nonenzymatic cofactor high molecular weight kininogen (HK), which is in complex with either PK or FXI [for a review, see 7]. Upon activation, 3 events occur: (1) activation of the intrinsic pathway of coagulation via activation of FXI by activated FXII, (2) release of bradykinin (BK) from the HK precursor by the action of activated $\mathrm{PK}$ and (3) the generation of antimicrobial peptides [for a review, see 7].

Streptococcus pyogenes is a major human pathogen that mainly causes superficial and self-limiting skin and throat infections, which can occasionally develop into serious and life-threatening conditions such as streptococcal toxic shock syndrome (STSS) and necrotizing fasciitis [for a review, see 8]. It was recently published that M1 protein, one of the classical virulence determinants of $S$. pyogenes, forms complexes with fibrinogen which then

\section{KARGER}

Fax +4161306 1234

E-Mail karger@karger.ch

www.karger.com
(C) 2009 S. Karger AG, Basel

1662-811X/09/0013-0225\$26.00/0

Accessible online at:

www.karger.com/jin
Dr. Sonja Oehmcke

Department of Clinical Sciences, Division of Infection Medicine, BMC, B14 Lund University, Tornavägen 10

SE-221 84 Lund (Sweden)

Tel. +46 46222 8592, Fax +46 4615 7756, E-Mail Sonja.Oehmcke@med.lu.se 
are able to activate PMNs [9]. In the present study we show that this activation also evokes very efficiently the formation of NETs. We further show that purified DNA as well as NET-DNA absorbs purified HK and FXII, and when added to plasma activates the contact system.

\section{Methods}

PMN Purification and Activation

PMNs were purified from blood of healthy donors using Polymorphprep (Fresenius) as described earlier [9]. The cells were washed and diluted in ME-Medium (Invitrogen) with HEPES buffer. Fifty microliters of $3 \times 10^{6}$ cells $/ \mathrm{ml}$ were seeded on polylysine-treated slides and activated with $100 \mathrm{mU} / \mathrm{ml}$ glucose oxidase (GO; Sigma) or $100 \mathrm{nM}$ IL-8 (Pepro Tech) or $5 \mu$ l of preformed M1 protein/fibrinogen complexes for $60 \mathrm{~min}$ (20 $\mu \mathrm{g}$ purified M1 protein [10] added to $6 \mathrm{mg}$ fibrinogen; the precipitate was suspended in $100 \mu \mathrm{l}$ MEM).

\section{DNA Preparation}

DNA from purified PMNs was isolated using the DNazol Reagent (Invitrogen) as described by the manufacturer.

\section{Measurement of PK Activity}

PK activity in human plasma was measured after activation with purified DNA as follows. Ten microgram per milliliter DNA together with the chromogenic substrate (S2302) was incubated with human plasma for $60 \mathrm{~min}$ at $37^{\circ} \mathrm{C}$. The absorbance was then measured after different time points at $405 \mathrm{~nm}$. As a control, DNA were degraded with $200 \mathrm{mU}$ DNase I (Ambion) for $30 \mathrm{~min}$ at $37^{\circ} \mathrm{C}$ before adding to plasma. To measure PK activity on activated PMNs, $200 \mu \mathrm{l}$ PMNs in MEM $\left(3 \times 10^{6}\right.$ cells $\left./ \mathrm{ml}\right)$ were stimulated with GO or IL-8 as described above. DNase I (200 mU; Ambion) was added to the controls and incubation was continued for 30 $\min$ at $37^{\circ} \mathrm{C}$. The supernatants were gently removed and the cells were incubated with human plasma from the same donor for another $15 \mathrm{~min}$ at $37^{\circ} \mathrm{C}$. After removing the plasma, cells were incubated in physiological salted sodium citrate buffer (13 mM) containing the chromogenic substrate (S2023). Absorbance was measured over a time period of $60 \mathrm{~min}$ at $37^{\circ}$.

\section{BK Measurements}

Different concentrations of purified DNA $(1,10$ and $100 \mu \mathrm{g} /$ $\mathrm{ml}$ ) were incubated with human plasma for $15 \mathrm{~min}$ at $37^{\circ} \mathrm{C}$, and the BK content was measured as described earlier [11]. As controls, DNA samples were degraded with DNase I prior to incubation with plasma.

\section{Statistical Analysis}

Statistical analysis was performed using GraphPadPrism 4.00. The $\mathrm{p}$ value was determined by using the unpaired test (comparison of 2 groups).

\section{Scanning Electron Microscopy}

Activated PMNs were immobilized on poly-lysine cover slides, before and after treatment with DNase I, fixed in 2.5\% (v/v) glutaraldehyde and prepared for scanning electron microscopy as described earlier [9].
Transmission Electron Microscopy

PMNs were activated as described above, and incubated with gold-labeled HK and FXII for $30 \mathrm{~min}$ at room temperature. Cells were then fixed with $2.5 \%$ glutaraldehyde, dehydrated and embedded in Epon as described earlier [9]. For negative staining, purified DNA $(20 \mu \mathrm{g} / \mathrm{ml})$ were mixed with $20 \mathrm{nM} \mathrm{HK}$ and $20 \mathrm{nM}$ FXII for $20 \mathrm{~min}$ at room temperature. Samples were then processed as previously reported [12].

\section{Results and Discussion}

\section{Activation of the Contact System by Soluble DNA Purified from PMNs}

In the present study we wished to investigate whether NETs can provide a surface that allows the assembly and activation of contact system. As the skeletal structure of NETs is primarily built up by PMN-derived DNA [1], in the first set of experiments we focused on soluble DNA purified from PMNs (also see Materials and Methods) and tested its interaction with the contact factors HK and FXII. To this end, purified human HK and FXII were incubated with DNA, negative stained, and examined with a transmission electron microscope. Figure la shows negative-stained DNA, HK and FXII. When all components were mixed together, the micrographs revealed that DNA avidly recruited HK and FXII, which, interestingly, were always found in proximity to each other. To test whether binding of HK and FXII to soluble DNA is followed by an activation of the contact system, we monitored PK hydrolysis in DNA-treated plasma. As shown in figure $1 \mathrm{~b}$, an increase in the cleavage of a PK-specific substrate was seen when soluble DNA was added to plasma, but not with DNase I-treated DNA. It should be noted that the DNase treatment had no influence on the activity of PK in kaolin-activated plasma, implying that hydrolysis of the PK substrate is not influenced by DNase or contaminants thereof (data not shown). Finally, we measured whether activation of $\mathrm{PK}$ is followed by the release of $\mathrm{BK}$, which was indeed seen when DNA was mixed with plasma and prevented when DNA was degraded by DNase I prior adding to plasma (fig. 1c). Taken together, the data demonstrate that purified DNA has the ability to assemble and activate the contact system.

\section{The Contact System Is Bound and Activated on NETs}

To test whether not only soluble DNA but also NETs can activate the contact system, PMNs were stimulated with glucose oxidase or IL-8. Both substances have been earlier reported to trigger NET formation [13] and this was also confirmed in our studies by fluorescence and 
Fig. 1. Purified DNA binds and activates the contact system. a Transmission electron microscopy of negative-stained DNA (yellow pseudo color) HK (red pseudo color), FXII (green pseudo color) or a mixture of all 3 molecules. b Measurement of PK activity after incubation of plasma with purified DNA $(10 \mu \mathrm{g} / \mathrm{ml})$. As a control, DNA was pretreated with $200 \mathrm{mU}$ DNase I for $30 \mathrm{~min}$ at $37^{\circ} \mathrm{C}$ before incubating in plasma. c BK release after incubation of DNA (10 or $100 \mu \mathrm{g} / \mathrm{ml}$ ) and the DNase Ipretreated controls in human plasma for $15 \mathrm{~min}$ at $37^{\circ} \mathrm{C}$. All Data represent the mean $+\mathrm{SD}(\mathrm{n}=3)$ of 1 representative of 3 independently performed experiments. ${ }^{* *} \mathrm{p}<0.01 ;{ }^{* *} \mathrm{p}<0.0001$. Scale bar $=10$ $\mathrm{nm}$.
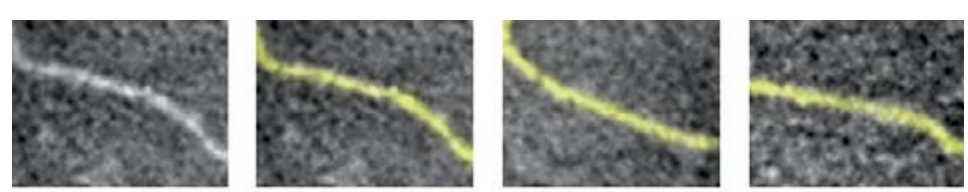

DNA
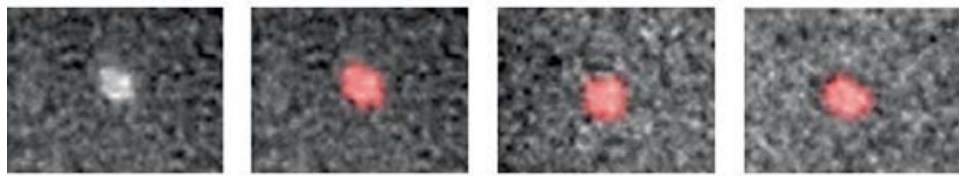

HK
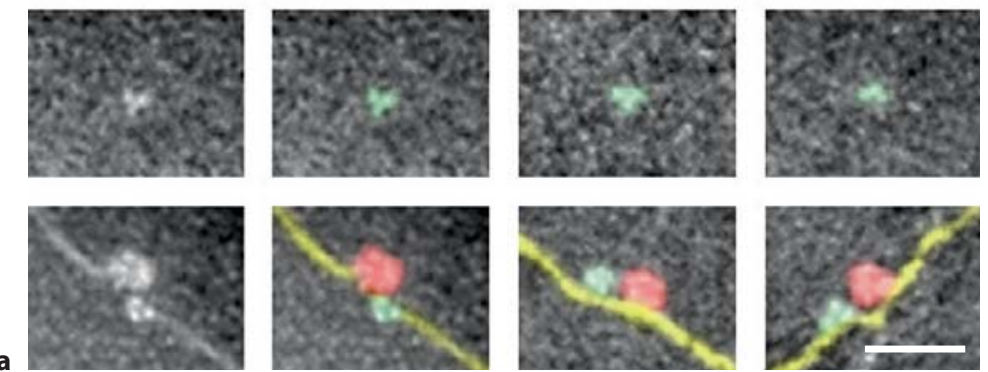

DNA/

HK/

FXII

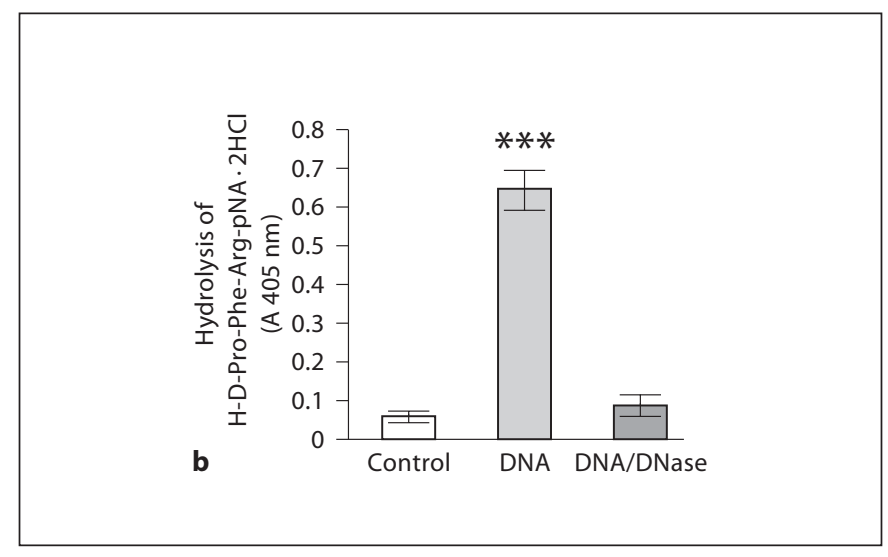

scanning electron microscopic analysis of PMNs activated with GO (fig. 2a) or IL-8 (data not shown). As expected, incubation of GO-stimulated PMNs with DNase I, led to a complete degradation of the NET structures (fig. 2a). In the next series of experiments, GO-activated PMNs were mixed with gold-labeled HK and FXII and further analyzed by transmission electron microscopy (Fig. 2b). Ultrathin sections of the stimulated PMNs revealed fine extracellular fibers, which were absent in the DNase Itreated control (fig. 2b). Furthermore, HK (small gold particles) and FXII (large gold particles) were exclusively attached to these fibers (fig. 2b) and, importantly, they were always found in close proximity to each other as seen before in experiments with soluble DNA (fig. 1a). To

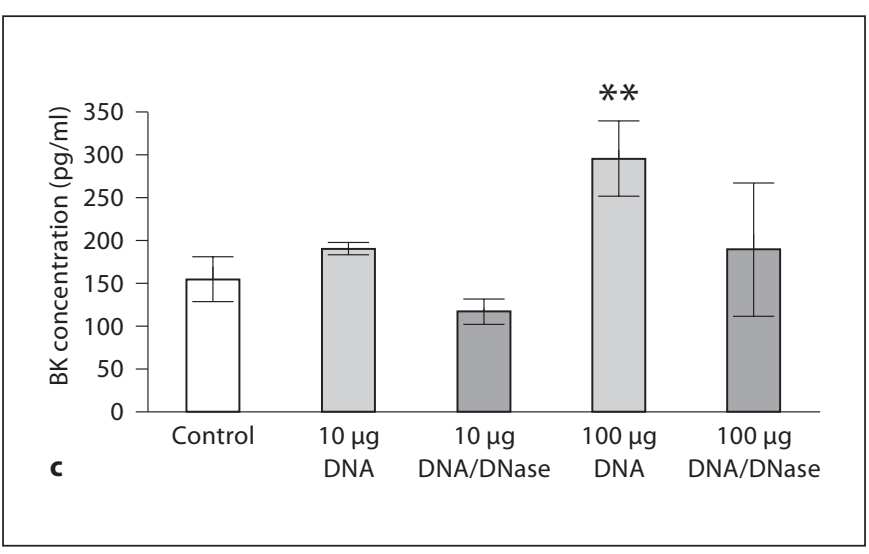

test whether the contact system is activated on NETs, we measured PK activity in plasma treated with nonactivated and activated PMNs. Figure $2 c$ depicts that the addition of nonactivated PMNs to plasma did not trigger an increase in PK activity, while GO- or IL-8-stimulated $\mathrm{PMNs}$ induced a significant rise, which was reduced to background levels when DNase I was added to the PMNs. Based on these findings we conclude that the contact activation occurs on NET fibers.

\section{M1 Protein/Fibrinogen Complexes Induce NET Formation}

There is a growing body of evidence showing that NETs can be generated upon activation of PMNs by im- 

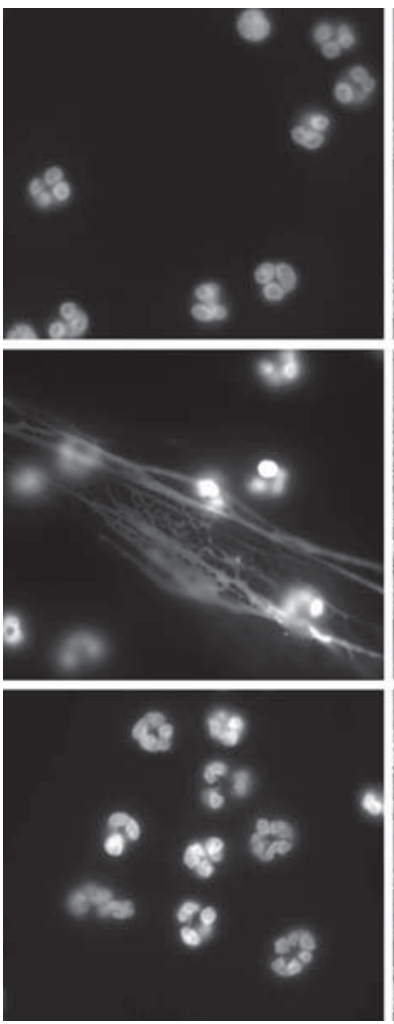
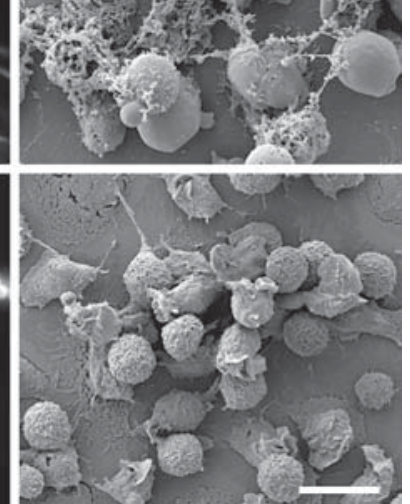

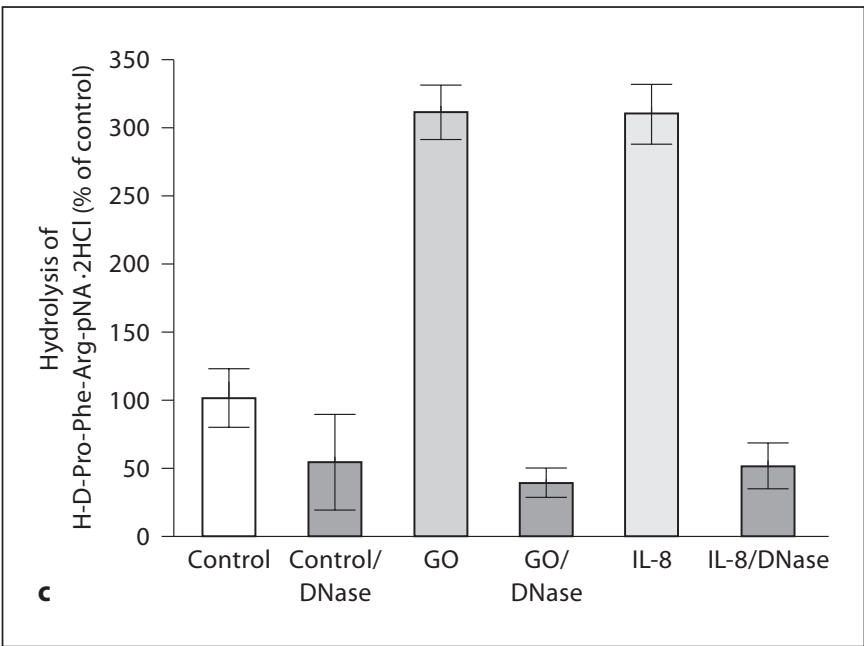

PMN/
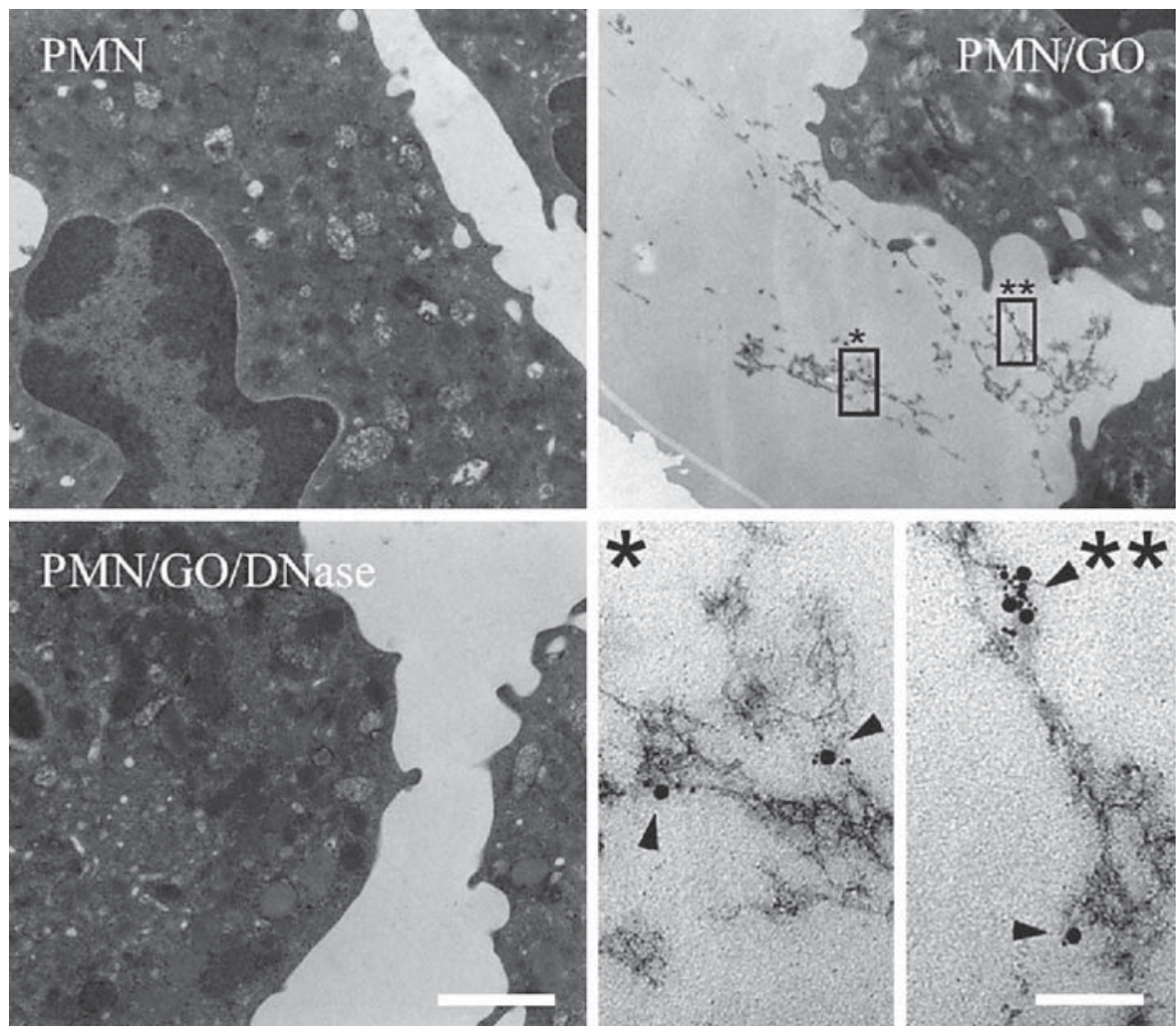

Fig. 2. NET-DNA binds contact system proteins, which is followed by activation of the contact system. a Light and scanning electron microscopy of nonactivated PMNs and PMNs activated with $100 \mathrm{mU} /$ $\mathrm{ml} \mathrm{GO}$ for $60 \mathrm{~min}$. As a control, PMNs were incubated with $200 \mathrm{mU}$ DNase I for $30 \mathrm{~min}$ after activation. Scale bar $=10 \mu \mathrm{m}$. b Transmission electron microscopy of nonactivated PMNs as well as PMNs stimulated with $100 \mathrm{mU} / \mathrm{ml} \mathrm{GO}$ and incubated with gold-labeled HK (small gold particles) and FXII (larger gold particles). Scale bar $=1 \mu \mathrm{m}$. A higher magnification of 2 areas (marked with ${ }^{*}$ and ${ }^{* *}$ ) showing the binding of gold-labeled contact factors to NETs is shown on the lower right (Scale bar $=100 \mathrm{~nm}$ ). Arrowheads point to goldlabeled proteins. PMNs incubated with $200 \mathrm{mU}$ DNase I after stimulation and before adding to gold-labeled proteins are shown on the lower left. c PK activity after incubation of GO- and IL-8-stimulated PMNs in human plasma. Results shown are a representative of at least 3 experiments with PMNs from 3 different donors. 
Fig. 3. NET formation after stimulating the PMNs with M1 protein/fibrinogen complexes. a, b PMNs were incubated with M1 protein/fibrinogen complexes for 60 min and investigated by light and scanning electron microscopy. c, d For light microscopy, the PMNs were stained with DAPI. As a control, the stimulated cells were treated with $200 \mathrm{mU}$ DNase I for 30 min. Arrowheads point to PMNs. Scale bar $=10 \mu \mathrm{m}$.
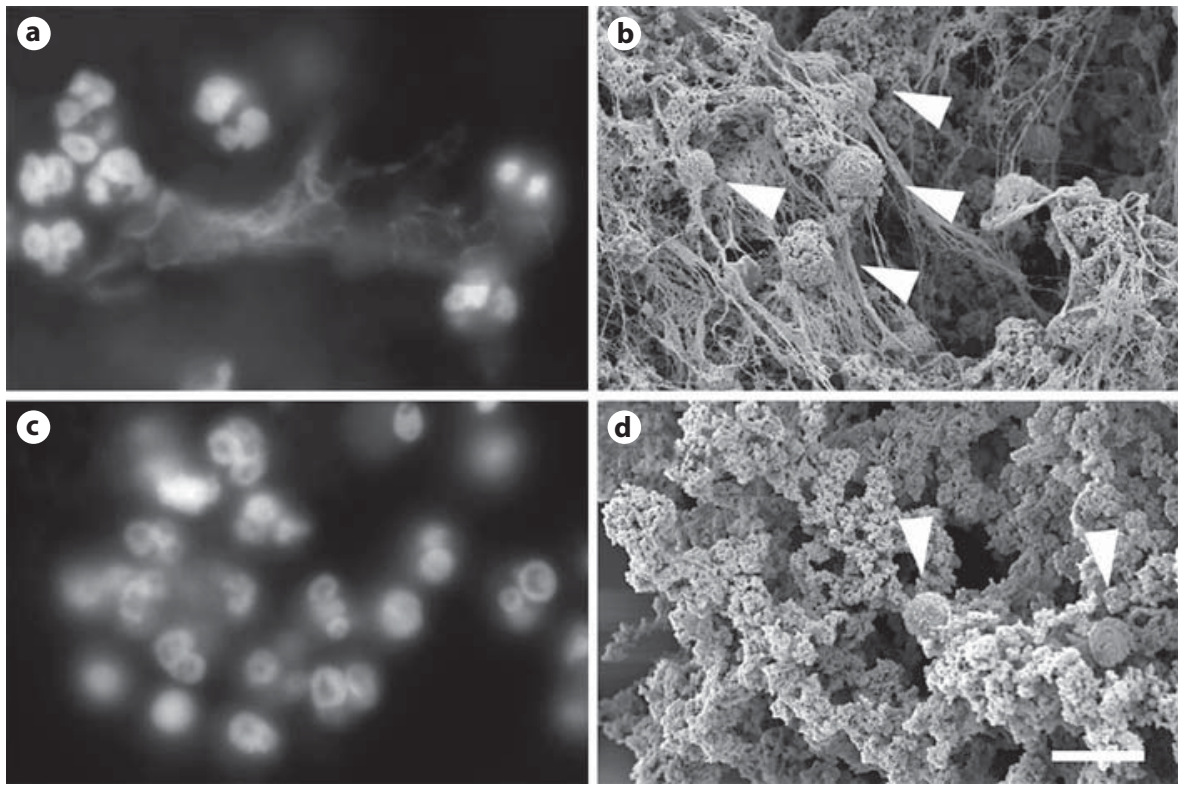

portant clinical pathogens such as Streptococcus pneumoniae, Salmonella typhimurium, Staphylococcus aureus or Shigella flexneri $[13,14]$. Also, lipopolysaccharide, a bacterial membrane component of Gram-negative bacteria, was proven to evoke NET formation [1]. We recently reported that soluble $\mathrm{M} 1$ protein of $S$. pyogenes forms complexes with fibrinogen which then trigger PMNs to mobilize their granular proteins [9]. Based on these findings, we were wondering whether this interaction also leads to the formation of NETs. PMNs were therefore incubated with M1 protein/fibrinogen complexes for 60 min and then subjected to analysis by fluorescence and scanning microscopy. Figure 3a shows that the treatment of PMNs with M1 protein/fibrinogen complexes induced a clumping of cells and the release of DNA. Analysis of the cell aggregates by scanning electron microscopy revealed that PMNs were entrapped within an amorphous precipitate built up by $\mathrm{M} 1$ protein/fibrinogen complexes and overlaid with NET fibers (fig. 3b). In PMN controls using M1 protein or fibrinogen alone, no aggregates or NET formation were observed (data not shown). Although DNase I treatment was able to dissolve the NET fibers, PMNs were still found in aggregates made up by M1 protein/fibrinogen complexes (fig. 3c, d).

The concept of contact activation on oligonucleotides is not entirely novel, as Kannemeier et al. [6] showed in 2007 that extracellular RNA provides a surface that allows activation of the contact system. However, we show here for the first time that extracellular DNA is also able to activate the contact system. Keeping in mind that contact activation leads to the processing of HK followed by the release of antibacterial peptides [15] and BK, a potent inflammatory mediator [for a review, see 16], it is tempting to speculate that the recruitment and activation of the contact system by NETs amplifies the innate immune response. On the other hand, streptococci may take advantage of the host defense mechanism and counteract in that they immobilize PMNs distantly from the infectious site by releasing M proteins which in concert with fibrinogen crosslink the cells and form an insoluble layer made of M1 protein/fibrinogen complexes around the PMNs. Whether or not the activation of PMNs by streptococci can neutralize the protective effect of NETs or even lead to systemic inflammatory reaction, needs to be unraveled.

\section{Acknowledgements}

We wish to thank Monica Heidenholm and Maria Baumgarten for excellent technical assistance, and Rita Wallén and Eric Hallberg, Cell and Organism Biology, Lund University, for support with electron microscopy.

This work was supported in part by the foundations of Alfred Österlund, Crafoord, Greta and Johan Kock, the Medical Faculty, Lund University, the Swedish Research Council (project 13413) and Hansa Medical AB. 


\section{References}

-1 Brinkmann V, Reichard U, Goosmann C, Fauler B, Uhlemann Y, Weiss DS, Weinrauch Y, Zychlinsky A: Neutrophil extracellular traps kill bacteria. Science 2004;303:15321325.

$>2$ von Köckritz-Blickwede M, Goldmann O, Thulin P, Heinemann K, Norrby-Teglund A, Rohde M, Medina E: Phagocytosis-independent antimicrobial activity of mast cells by means of extracellular trap formation. Blood 2008;111:3070-3080.

>3 Hojima Y, Cochrane CG, Wiggins RC, Austen KF, Stevens RL: In vitro activation of the contact (Hageman factor) system of plasma by heparin and chondroitin sulfate E. Blood 1984;63:1453-1459.

$\checkmark 4$ Espana F, Ratnoff OD: Activation of Hageman factor (factor XII) by sulfatides and other agents in the absence of plasma proteases. J Lab Clin Med 1983;102:31-45.

$\checkmark 5$ Tans G, Griffin JH: Initiation of contact activation by sulfatides. Adv Exp Med Biol 1983;156:63-72.

6 Kannemeier C, Shibamiya A, Nakazawa F, Trusheim H, Ruppert C, Markart P, Song Y, Tzima E, Kennerknecht E, Niepmann M, von Bruehl ML, Sedding D, Massberg S, Gunther A, Engelmann B, Preissner KT: Extracellular RNA constitutes a natural procoagulant cofactor in blood coagulation. Proc Natl Acad Sci USA 2007;104:6388-6393.
Frick IM, Björck L, Herwald H: The dual role of the contact system in bacterial infectious disease. Thromb Haemost 2007;98:497502.

8 Cunningham MW: Pathogenesis of group A streptococcal infections. Clin Microbiol Rev 2000;13:470-511.

9 Herwald H, Cramer H, Mörgelin M, Russell W, Sollenberg U, Norrby-Teglund A, Flodgaard H, Lindbom L, Björck L: M protein, a classical bacterial virulence determinant, forms complexes with fibrinogen that induce vascular leakage. Cell 2004;116:367-379.

10 Påhlman LI, Olin AI, Darenberg J, Mörgelin M, Kotb M, Herwald H, Norrby-Teglund A: Soluble M1 protein of Streptococcus pyogenes triggers potent $\mathrm{T}$ cell activation. Cell Microbiol 2008;10:404-414.

11 Mattsson E, Herwald H, Cramer H, Persson K, Sjöbring U, Björck L: Staphylococcus aureus induces release of bradykinin in human plasma. Infect Immun 2001;69:3877-3882.
12 Herwald H, Mörgelin M, Svensson HG, Sjöbring $\mathrm{U}$ : Zinc-dependent conformational changes in domain D5 of high molecular mass kininogen modulate contact activation. Eur J Biochem 2001;268:396-404.

13 Fuchs TA, Abed U, Goosmann C, Hurwitz R, Schulze I, Wahn V, Weinrauch Y, Brinkmann V, Zychlinsky A: Novel cell death program leads to neutrophil extracellular traps. J Cell Biol 2007;176:231-241.

14 von Köckritz-Blickwede M, Goldmann O, Thulin P, Heinemann K, Norrby-Teglund A, Rohde M, Medina E: Phagocytosis-independent antimicrobial activity of mast cells by means of extracellular trap formation. Blood 2008;111:3070-3080.

15 Frick IM, Åkesson P, Herwald H, Mörgelin M, Malmsten M, Nägler DK, Björck L: The contact system - a novel branch of innate immunity generating antibacterial peptides. EMBO J 2006;25:5569-5578.

16 Leeb-Lundberg LMF, Marceau F, Müller-Esterl W, Pettibone DJ, Zuraw BL: International union of pharmacology. XIV. Classification of the kinin receptor family: From molecular mechanisms to pathophysiological consequences. Pharmacol Rev 2005;57: 27-77. 